\title{
A trial regarding the baropodometric indexes for patients who had a cerebrovascular accident
}

\author{
Danelciuc Francisc Tadeus ${ }^{1}$, Danail Sergiu, ${ }^{2}$ Sînziana Călina Silisteanu ${ }^{3}$ \\ 1.Kinetic therapist - "Stefan cel Mare" University of Suceava \\ 2.Phd - USEFS, Chisinau, Republica Moldova \\ 3. Railway Hospital Iasi - Specialty Ambulatory of Suceava - "Stefan cel Mare" University of Suceava
}

\begin{abstract}
The cerebrovascular accident is associated to the alteration of the static and dynamic balance in orthostatism, during the walk and in the sitting position. There are 65,000 people who have a cerebrovascular accident every year, namely 178 cases a day. For patients who had a cerebrovascular accident, it is essential to divide the recovery period into stages. A third of these patients have various disability degrees. It may sometimes be noticed that the patients who had a cerebrovascular accident have a temporary synchronization of the legs and of the abdomen or only of the legs. The deficit to fix the position of the body segments among them or with the environment may influence the postural stability. The current trial evaluates the possibilities to regain the postural control and the walk for the patients who have a motor deficit after they had a cerebrovascular accident by an individual program of recovery sessions. The exteroceptive sensations at the level of the foot sole are import in order to maintain the stability and the balance as well as in order to reeducate the postural control. The postural stability is determined by the maintenance of the balance by the intervention of the myo-arthric kinetic system and it imposes the maintenance of the projection of the weight centre inside the support base. The maintenance of the stability is a dynamic process that involves the attempt to stabilize and to destabilize the action forces. In order to keep a steady position, it is possible to move the weight centre or to increase the surface of the support base. The baropodometry is a non invasive technique that enables the obtainment of information related to the biomechanics of the human body, by setting up the flaws of the plantar support and by measuring the plantar pressure in static conditions. The use of this device during the walk has effects upon the efficiency of the movements, on the stability of the joints, on the maintenance of a correct posture and on the muscular coordination.
\end{abstract}

Key word: baropodometry, postural control, MBT physiotherapy device

\section{Introduction}

Romania is on the $3^{\text {rd }}$ place in Europe, after Bulgaria and Macedonia in relation to the incidence of the cerebrovascular accident and the mortality rate by cerebrovascular diseases. There has recently been an increased incidence of cerebrovascular accidents for the people aged under 30 whereas $31 \%$ of the patients who had a cerebrovascular accident are $20-$ 64 years old, in comparison to the year 1990, when the incidence was $25 \%$.

The mortality rate because of cerebrovascular accidents for the persons aged 65 is 1,276 patients among 100,000 inhabitants, in comparison to the European countries where the death incidence is 300 patients among 100,000 inhabitants.

The cerebrovascular diseases are considered to determine death in a ratio of $4 / 1$ for the Romanians in comparison to the Europeans and $7 / 1$ in comparison to the Americans. According to the statistic data, $10 \%$ of the population die from cerebrovascular accidents. The latter are estimated to become in 2030 the main cause of death in the world, namely 8 million deaths. For patients who had a 
cerebrovascular accident, it is essential to divide the recovery period into stages. The deteriorated functions may be repaired in the first 6 months after the cerebrovascular accident. The patients may recover fully or partially according to the location and effort. There are 65,000 people who have a cerebrovascular accident every year, namely 178 cases a day. A third of these patients have various disability degrees. It is very important to prevent the cerebrovascular accident the second time because there is a risk of almost 9 times greater to repeat it, 4-5 times greater to have IMA and 3-4 times greater to have arteriopathy in the lower limbs.

It is necessary to take into consideration the behavior disorders, the cognitive functions as they are signs of the vascular dementia. The factors that trigger the cerebrovascular accident and that may be modified are: blood pressure, smoking, alcohol consumption, sedentary state and diabetes mellitus. There are risk factors that may not be modified: the age, the human race, the genetic predisposition and the gender.

The cerebrovascular accident may determine sensory and motor deficit, speech and postural control deficit. [1] In order to regain the functional independence of the patient, it is important to reeducate the postural control after the cerebrovascular accident. [2] In order to achieve the postural stability, it is

necessary to fix the position of the various body segments among them/ with the environment. It may sometimes be noticed that the patients who had a cerebrovascular accident have a temporary synchronization of the legs and of the abdomen or only of the legs.

The trials show that the distal segment of the sick low limb is no longer steady, which comes from the postural instability in the vertical position, not in the stability of the abdomen.

The leg in varus equin is a complication of the spasticity by modifying the support area with the instability. [3], [4], [5] This is why the position of spastic varus equin determines the biomechanical instability of the leg, namely the postural instability. [6]
If the instability is accompanied by severe paresis/sensory deficit, it may influence the recovery of the patient who had a cerebrovascular accident. [7] The slight spasticity enables the continuity of the static vertical position by counterbalancing the negative effects dominated by the low muscular force upon the vertical position . The deficit to fix the position of the body segments among them or with the environment may influence the postural stability.

In order to reeducate the static postural coordination and the dynamic one, it was important to analyze the transfer of the weight from the sitting/standing position, the walk, and the movements of the upper limbs. In some cases, certain adapting voluntary or involuntary components may compensate / substitute the functional deficit.

It has frequently been noticed that the support area is enlarged, the body deviates towards the healthy leg whereas the muscles are contracted in order to keep the balance. Thus, the movements of the upper limb are towards lateral side, by rotating the sick limb internally.

The cerebrovascular accident is associated to the alteration of the static and dynamic balance in orthostatism, during the walk and in the sitting position. Thus, the balance between the agonist musculature and the antagonist one is modified within the cinematic chains, especially at the level of the lower limbs whereas the mechanisms of sensitive and motor integration are altered at the cortical level and influence the control-coordinationbalance functions, implicitly the postural control.

The current trial evaluates the possibilities to regain the postural control and the walk for the patients who have a motor deficit after they had a cerebrovascular accident by an individual program of recovery sessions.[8] The posture is defined as being determined by the position of the segments among them towards the body and by the position of the body towards the environment in the relaxing moments and during the activities. [9], [10] The posture is the result of the neuromuscular 
action whereas the purpose is to maintain the body balance. [11]

The postural control involves the stability and the balance (the static one and the dynamic one).

There are numerous researches about the role of the information from the somatic sensors in order to maintain the balance and the stability of the body for the normal persons [12], [13] and for the persons who have different pathologies. [13], [14], [15]

The proprioceptors convey information about the tendons, the muscles and the joints whereas the exteroceptors provide with data about the spatial orientation of the body segment but also of the entire body. [16]

The exteroceptive sensations at the level of the foot sole are import in order to maintain the stability and the balance as well as in order to reeducate the postural control. [17]

The recovery of the balance for the patient who have a cerebrovascular accident, Parkinson, Alzheimer and degenerative diseases in the joint involve disturbance at the level of the ankles, of the abdomen and of the walk.

The more important the vestibular and sensory conditions and the myo-neural conditions in the joints are, the more influenced the balance, the stability and the postural control are.

The lack of balance between the sensory system and the motor one together with the nervous system condition may influence the automatic postural responses that are triggered when the projection of the weight centre is not within the support area.

The automatic postural responses are stereotype movements, with a very short latency . According to the intensity of the stimulus that causes disequilibrium, the postural responses may involve the following strategies:

-the strategy of the ankles for a slight disequilibrium: it consists of slight amplitude oscillations around the joints of the ankles whereas the pressure on the ground is modified and the body gains balance.

-the strategy of the abdomen for a greater intensity disequilibrium: the straightening is made by oscillations of the trunk and of the abdomen while involving the abdominal muscles, the quadriceps muscles and the tibia anterior muscles.

-the strategy of the suspension: it involves the flexion of the knees in order to lower the weight centre.

-the strategy of the walking steps: it involves the execution of 1 or 3 step at the moment of the disequilibrium, which is associated to the movements of the upper limbs. [18]

The anticipating postural adjustments are the movements or the sequences of movement whose purpose is to prevent the disequilibrium and to improve the body stability. They rely on the all the medullary engrams and they are adapted to the imposed conditions.

The postural stability is determined by the maintenance of the balance by the intervention of the myo-arthric kinetic system and it imposes the maintenance of the projection of the weight centre inside the support base.

The maintenance of the stability is a dynamic process that involves the attempt to stabilize and to destabilize the action forces. Under each leg that has a rest, there are points of the pressure centre but the main pressure centre is in the middle of the support base. In order to keep a steady position, it is possible to move the weight centre or to increase the surface of the support base. [19]

The postural orientation is more important than the stability. [20]

The posturology is a science that deals with the interdisciplinary study of the posture, with the automatic motor and conscious control that is necessary to the adoption and to the stabilization of a posture which has a rest or which moves.

The muscular activity is important in the making of a posture because it must generate forces that will interact in a dynamic way with external mechanic forces: the gravitational force, the friction forces and the inert force).

The stability in the orthostatism and in the walk depends on the position of the weight centre and it is directly proportional to the size of the support polygon. The orthostatic posture results from the motor efferences for the musculature of the trunk and of the lower limbs; it is under the control of the vestibular 
system and of the reticulated formation. Some of the factors that influence the

postural stability are: the geometric shape and the sizes of the support base, the position of the body weight, the alignment of the segments, the muscular activity, the psychological state of mind and the pathological factors.

The kinetic therapy program included: breathing exercises, Kabat diagonals, techniques to enable the improving elements of the motor control: the mobility, the stability, the ability and the controlled mobility.

\section{STATISTICS}

The calculation of the statistic parameters was used for the statistical analysis interpretation of the data: the arithmetic average, the standard average mediation, the variability coefficient and the Pearson correlation coefficient.

\section{OBJECTIVES:}

-the analysis of the efficient recovery program by kinetic therapy, of the postural control and of the walk for the patients who were diagnosed with the cerebrovascular accident by dividing into stages the recovery program of the postural control for the patients who had a cerebrovascular accident. -the planning and the adaptation of the

recovery program of the postural control and of the walk by using MBT physiotherapy devices for the patients who had a cerebrovascular accident. This why the use of these devices in the recovery of the postural control after the cerebrovascular accident involves the setting up of an individual program of kinetic therapy.

\section{Material and method}

The recovery of the walk and of the balance is important for the patients who had a cerebrovascular accident. The weight of a healthy person is divided equally on both legs. After several trials carried out on the footprints, it was found out that the leg does not stand up on the support area in separate points (corresponding to the bony prominences) but on an area due to the plantar muscles and to the plantar adipose tissue.

The pressure plantograms in the sitting position points out increased values around the calcaneus, the ends of the first and fourth metatarsal bones. This why, by placing the leg on an area that takes the shape determined by the curved line of the plantar surface of the leg (as it is the case of applying the MBT physiotherapy device), the distribution of the pressure is made equally from the heels to the metatarsals bones.

The walk is a motor skill that enables the body to move in a certain direction by providing postural stability and balance. The walk has two stages: support and move on the left and on the right balance. The support means the contact between the foot and the ground and it takes approximately $60 \%$ of the walking cycle in comparison to the balance which does not involve the contact with the ground and which takes $40 \%$ of the walking cycle.

The recovery of the balance disorders and of the postural stability involves the education and the reeducation of the motor action.

The baropodometry is a non invasive technique that enables the obtainment of information related to the biomechanics of the human body, by setting up the flaws of the plantar support and by measuring the plantar pressure in static conditions. [21]

The patients must keep their sitting positions for 5 minutes on the platform and must keep their eyes open in order to avoid the oscillations. This device made it possible to visualize and to monitor the maximal pressures exerted at the plantar level, the baric pressure and the support area. [22]

Thus, the following baropodometric parameters were analyzed: the plantar area $\left(\mathrm{cm}^{2}\right)$, the plantar baric pressure $(\mathrm{kPa}, \%)$, the baric pressure on plant segments on the anterior side and on the posterior side (\%), the anterior-posterior oscillations (in the sagittal side) and the lateral left-right oscillation (in the frontal side).

Several scales were used in order to make a clinical and functional evaluation of the patients who had a cerebrovascular accident.

-the Berg scale for the evaluation of the balance. [23]

The state of the patient in the sitting/standing position was monitored daily whereas the core 
was calculated and interpreted according to the scale. [24]

-the Fugl-Meyer scale for the evaluation of the different sensitivity disorders in the sick lower limbs. [23]

The exercise program enables the functional recovery and also the development of the social, professional, psychical and communicative functions.

The recovery program involves:

- the development of the basic physical qualities for the motor activities

- the obtainment of the adequate motor skills in order to carry out the ADL

- the development of the sense at the myo arterial kinetic level

- the provision of the self-control ability in order to avoid accidents

- the maintenance of a right body attitude/position

- the provision of an individual kinetic therapeutic programme

The trial was carried out for a period of 6 months for a group of 73 patients out of which 48 had a cerebrovascular accident (the trial group) and 25 healthy persons (the witness group). The purpose was to follow the dynamics of the balance parameters by using the MBT device. The average age of the group was $55,6+/-8,6$.

The use of the baropodometric platform aimed at following the parameters: the bilateral plantar area, the barric pressure of the pressure centre for each plant, the oscillations in the frontal side and in the sagittal side.

\section{For the patients who had a cerebrovascular} accident on the right side

The results from 19 patients showed an increase of the location of the pressure centre towards the healthy lower membre whereas the results from 3 patients showed a deviation to normal limits and for 2 patinets a deviation towards the paretic lower limb.(table 1)

Table no. 1 The baropodometric parameters for the patients with hemiparesis on the right side

\begin{tabular}{|l|c|c|c|c|c|c|}
\hline \multirow{2}{*}{$\begin{array}{l}\text { Baropodometric } \\
\text { parameters }\end{array}$} & without MBT & $\mathrm{pl}$ & \multicolumn{2}{|c|}{ with MBT } & \multirow{2}{*}{$\mathrm{p2}$} \\
\cline { 2 - 3 } \cline { 5 - 6 } & witness group & exp.group & & witness group & exp.group & \\
& $\mathrm{N}=25$ & $\mathrm{~N}=24$ & & $\mathrm{~N}=25$ & $\mathrm{~N}=24$ & \\
\hline SPD $\left(\mathrm{cm}^{2}\right)$ & 88.25 & 98.64 & $>0,05$ & 83.67 & 90.64 & $<0,05$ \\
\hline SPS $\left(\mathrm{cm}^{2}\right)$ & 86.85 & 90.12 & $>0,05$ & 87.88 & 88.8 & $<0,05$ \\
\hline PBLS $(\%)$ & 51.13 & 58.47 & $<0,05$ & 51 & 55.83 & $<0,05$ \\
\hline PBLD $(\%)$ & 48.87 & 41.53 & $<0,05$ & 49 & 44.17 & $<0,05$ \\
\hline
\end{tabular}

The plantar areas showed greater significant modifications from a statistical point of view for the trial group than for the witness group.

For the patients who had a cerebrovascular accident on the right side

It was found out that the pressure centre was located towards the healthy side in 14 patients whereas 2 patients had deviation to normal limits and 3 patients showed a deviation towards the sick side.(table 2)

Table no.2 The baropodometric parameters for the patients with hemiparesis on the left side

\begin{tabular}{|l|c|c|c|c|c|c|}
\hline Baropodometric & without MBT & \multirow{2}{*}{$\mathrm{pl}$} & \multicolumn{2}{|c|}{ with MBT } & \multirow{2}{*}{$\mathrm{p} 2$} \\
\cline { 2 - 3 } \cline { 5 - 6 } parameters & witness group & exp.group & & witness group & exp.group & \\
& $\mathrm{N}=25$ & $\mathrm{~N}=19$ & & $\mathrm{~N}=25$ & $\mathrm{~N}=19$ & \\
\hline SPD(mm) & 88.25 & 91 & $>0,05$ & 83,67 & 89.3 & $<0,05$ \\
\hline SPS (mm) & 86.85 & 97.25 & $>0,05$ & 87,88 & 92.33 & $<0,05$ \\
\hline PBLS (\%) & 51.13 & 40.04 & $<0,05$ & 51 & 43.25 & $<0,05$ \\
\hline PBLD (\%) & 48.87 & 59.96 & $<0,05$ & 49 & 56.75 & $<0,05$ \\
\hline
\end{tabular}

After analysing the baropodometric parameters of the indexes of the oscillations in the frontal side (anterior and posterior) and sagittal (lateral and lateral) in order to evaluate the static stability for the evaluated patients who had a cerebrovascular accident, the following images could be recorded (graph 1 and 2):

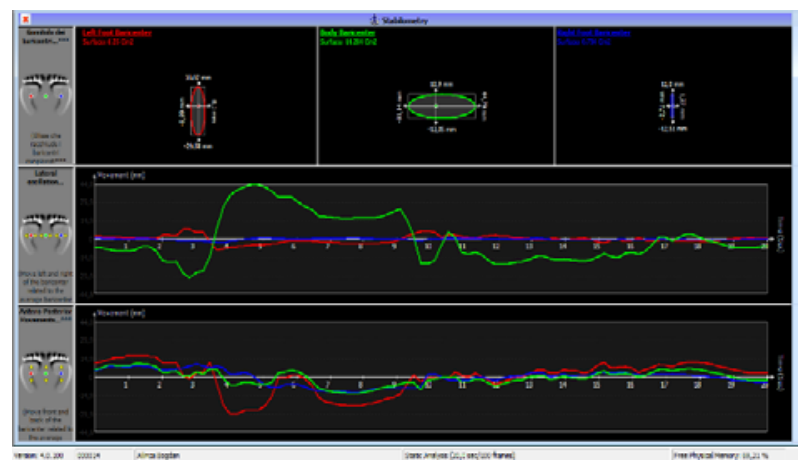

Graph no 1 The oscillations in the frontal side 


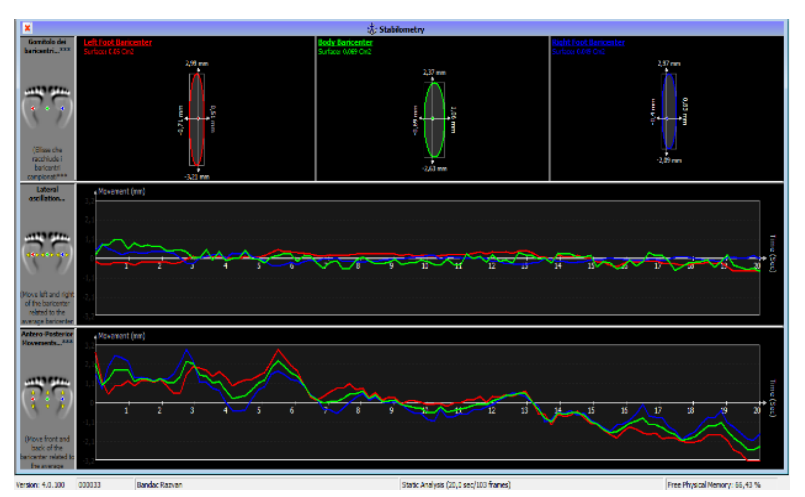

Graph no 2 the oscillations in the sagittal side The use of this device during the walk has effects upon the efficiency of the movements, on the stability of the joints, on the maintenance of a correct posture and on the muscular coordination.

The sensory and motor training by using the MBT device is useful for the reeducation of the stability and of the walk whereas the feedback mechanism has effects upon the joints and tendons by preventing the accidents.

\section{Results}

According to the clinical trials, the MBT physiotherapy device improves the patients' mobility and the motor performance, it increases the amplitude and it prevents the falls.

The use of this device during the walk has effects upon the efficiency of the movements, upon the stability of the joints, upon the maintenance of a correct posture and upon the muscular coordination.

The sensory and motor training by using the MBT device is useful for the reeducation of the stability and of the walk whereas the feedback mechanism has effects upon the joints and tendons by preventing the accidents.

The use of the MBT physiotherapy device is useful for the following reasons:

-the balance is maintained because the projection of the is steady in the support polygon

-the tonus of the musculature in the legs, buttocks and abdomen is kept staedy and it has a role in the orthostatism

-the plantar touching tactili receptors are stimulated

-the pressure centres are created on the outside and inside the plant
The MBT physiotherapy device may cause instability in the anterior/posterior side and in the median/lateral side during the walk, contributing thus to the tonified musculature which stabilises the anterior and lateral musculature of the leg, the tonified posterior musculature of the leg and it increases the mobility in the joints, especially on the dorsal flexion.

\section{Conclusions}

The trial enabled the emphasis of the technique and the methodics of the recovery programme by using the MBT physiotherapy device

The baropodometric platform is useful in the evaluation of the balance and of the postural control by using the MBT physiotherapy device only in the stability area. The advantage of this method consists in the possibility of using this device both in the static conditions and in the dynamic ones. So that the patients are educated to control their posture by themselves.

The results of the recovery programme are determined by the physical, psychical qualities of the patients but also by the motor achievements according to the period that passed since the outbreak of the condition.

The use of the MBT physiotherapy device is useful in the recovery of the balance and of the postural control.

\section{References}

1. Agapii E. Recuperarea controlului postural la persoanele după accident vascular cerebral în baza programei de kinetoterapie cu efecte de transfer funcţional. Teză de dr. în pedagogie. Chişinău, 2011. p. 172.

2. Băjenaru O. Ghiduri de diagnostic şi tratament în neurologie, Bucureşti: Medicală Amaltea, 2010. p. 148-163.

3. Calais-Germain, Blandine, Anatomie pentru mișcare. Introducere în analiza tehnicilor corporale, vol.1, Iași: Editura Polirom, 2009. p. 40-48.

4. Danelciuc, F.T., Danail, S., Impactul MBT asupra recuperării controlului postural la pacienții post AVC, în cadrul Conferinţei științifice interanționale "Cultura fizică și sportul într-o societate bazată pe 
recunoaștere". Chișinău; USEFS 6-7. 11. 2015. P. 365-369.

5. Dimulescu D., Chiriţi G., Terapia posturală în afecțiunile aparatului locomotor. din București: Universității din București, 2008, 167 p.

6. Gelu, O.,Recuperare, medicină fizică şi balneoclimatologie. Noţiuni de bază şi actualităţi. Volumul I. Bucureşti: Medicală, 2008, p. 105-237.

7. Moţet D. Psihologia recuperării handicapurilor neuromotorii. Partea I. Bucureşti: 2001, p. 57 - 64 .

8. Danelciuc. F.T., Silisteanu,C., The recovery of the postural equilibrium by balancing the baric pressure at the level of the lower limbs for patiens who had a stroke by using the MBT device, Iasi, 2016.

9. Gelu, O., Compendiu de neuroreabilitare la adulţi, copii şi vârstnici, Bucureşti: Universitară "Carol Davila", 2008, p. 14-15, 26-45, 47-55, 219-231, 398-403, 523-611.

10. Tyson S., Selley A. A content analysis of physiotherapy for postural control in people with stroke: An observational study. Disability and Rehabilitation. Volume 28, Numbers 1314, 2006 , p. 865

11. Sbenghe T. Bazele teoretice şi practice ale kinetoterapiei. Bucureşti, Editura Medicinală, 1999, pg. 236-272.

12. Cojocariu D., Danail S., Agapii E., Pascal O. Recuperarea cordonării și a echilibrului în activităţile de bază la persoanele după accident vascular cerebral prin tehnici de biofeedback stabiligrafic. Chișinău: USEFS, 2013. p.180.

13. Danelciuc F.T., Hasnaș D. Aspecte legate de recuperarea controlului postural prin Kinetoterapie bazat pe transferul calităţilor și deprinderilor la persoanele post AVC. În cadrul Conferinței științifice internaţională studențească "Probleme actuale ale teoriei și practicii culturii fizice" ediția a XV-a, Chișinău: USEFS 13.05.2011. P. 134-138.

14. Alexe D.I.,Implicațiile psihomotricității în manifestarea echilibrului la pubertate, Performantica Iași, 2012, p. 50

15. Pascal O. Tulburări ale controlului postural la bolnavii cu accident vascular cerebral: aspecte neurofiziologice, clinice şi de recuperare. Chişinău: Teză de dr. hab. în medicină. 2008, p. 207.

16. Tătaru AM, Kinetoterapia în afecțiunile neurologice, Iași: Ale, 2006. p. 175.

17. Netter, F. Neurology and neurophysiology atlas, Churchill-Livingstone, 2006. p. 191

18. Sbenghe T. Kinesiologie. Ştiinţa mişcării. Bucureşti: Medicinală, 2002, pg. 365-395;

19. Pásztai Z. Rolul stretchingului în normalizarea funcţiei stato-kinetice. Iaşi: Corsan, 2009, p. 47.

20. Danelciuc, F.T., Danail.S., Dan. M., Sindroamele associate și influența acestora în manifestarea tulburărilor posturale la persoanele post AVC, în cadrul Congresului Ştiințific Internațional "Spot. Olimpism. Sănătate" Chișinău; USEFS, 5-8.10.2016.

21. Cordun M. Kinantropometrie, Bucureşti: CD PRESS, 2009, p. 188-191.

22. Wikstrom, E.A., Arrigenna, M.A., Tillman, M.D., Borsa, P.A. (2006) - Dynamic Postural Stability in Subjects With Braced, Functionally Unstable Ankles, PubMed, J. Athl. Train. (vol. 41), pag. 245-250;

23. Roxana P., Rodica T., Badea P., Ghid de evaluare clinică și funcțională în recuperarea medicală. Craiova: Medicală Universitară, 2004. p. 91-92; 139-155; 215-218; 360-373;

24. Browne, J.E., O’Hare, N.J. (2005) - A Review of the Different Methods for Assessing Standing Balance, Science Direct, Physiotherapy (vol. 87), p. 489- 495; 